\title{
It's not just a brand name: The impact of language on consumer attitude and behavior
}

de Run, Ernest Cyril

Universiti Malaysia Sarawak, Malaysia (drernest@feb.unimas.my)

Yee, Teh Chin

RHB Bank Berhad, Perak, Malaysia (cy_crabtree11@yahoo.com)

Khalique, Muhammad $\bowtie$

Universiti Malaysia Sarawak, Malaysia (cks748@gmail.com)

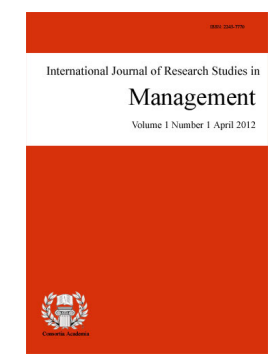

ISSN: 2243-7770

Online ISSN: 2243-7789

OPEN ACCESS

\section{Abstract}

This paper notes the impact of language choice in a brand name on consumer's response. This was measured based on three different language based brand names in the same product category (coffee). The brand names were Aik Cheong, Kopimas, and Power Root, representing Chinese, Malay, and English language respectively. Speech Accommodation Theory (SAT) is used as the basis for this paper as it indicates that a group prefers its own language and will respond positively. Data was collected from Chinese respondents throughout Malaysia using a survey. Questions were from past measurement scales utilizing a 6 point forced scale. The findings indicate that respondents preferred English and Chinese language brand name over Malay language brand name and there was no difference in response for English and Chinese language brand name. Malay language was the least preferred. This paper is limited by the method, breath and scope of data collection.

Keywords: brand name; language; Chinese; Malaysia; consumer attitude 


\section{It's not just a brand name: The impact of language on consumer attitude and behavior}

\section{Introduction}

Malaysia is a multi-racial and therefore multi-lingual country with a number of speech communities (Omar, 1982; Department of Statistics Malaysia, 2007). The national and official language of Malaysia is Bahasa Malaysia. It is also the medium of instruction in primary and secondary schools. English is the second most important language in Malaysia is commonly used for a variety of functions in professional and social transactions (Hashim, 2003). Other major languages are Mandarin (and the various Chinese dialects) and Tamil, which are taught in the national type schools and used within the subgroups. Most Malaysians are at the very least bilinguals and many are multilingual (Omar, 1982).

This diversity in language has also impacted the choice of brand names in the Malaysian market. Names such as Gardenia, Julie, Power Root and Old Town represent the English language's brand names while Saji, Jati, Syahirah, and Suria represent the use of Bahasa Malaysia brand names. In addition there are also Chinese language brand names such as Aik Cheong, Poh Kong, Lee Fah, and Chek Hup. It is clear that cultural differences and especially language difference will influence the way a product may be marketed, its brand name and the advertising campaign chosen (Doole \& Lowe, 1999). Therefore, it is important to study the impact of language use in brand names on Malaysian consumers. This paper will only look at the Malaysian Chinese consumer. The Chinese are the second largest ethnic group in Malaysia.

\section{Literature review}

Brand naming is an essential component in marketing strategy. It can contribute significantly to the success or failure of new products or services (Kotler \& Armstrong, 1997). The selection of the right brand name is one of the most important marketing decisions (Keller, 1993). A good brand name enjoys high levels of consumer brand awareness and commands strong consumer preference (Chan \& Huang, 1997).

Malaysia is not yet a significant global brand player as the brand value is not more than US 2.7 billion but Malaysia is proud of its many international brands such as Petronas, Air Asia, and Royal Selangor. The Malaysian government through its Ministry of International Trade and Industry and has been allocating funds and grants up to RM1 million to companies to undertake the development and promotion of Malaysia brands. This is done through the Brand Promotion Grants where SMEs are allowed for 100 percent reimbursable funding grant (Ahmad \& Baharun, n.d.).

In Malaysia, local brand names can be found in various languages. The brand names such as Munchy, Gardenia, Julie, and Old Town represent the English language's brand names while Seri Murni, Jati, Kapal Api, and Zaitun represent the use of Bahasa Malaysia in local brand names. Besides, there are also Chinese language brand names such as Aik Cheong, Poh Kong, Sin Tai Hing, and Chek Hup. The use of various languages in local brand names is because of diversity in the Malaysian diaspora.

The branding strategy for nondurable consumer products must always be related with the local culture (Boddewyn, Soehl, \& Picard, 1986). Companies are quick to act on this, utilizing brand names in their target market language and using it as a cue to indicate who the producer is. A brand name such as Seri Murni may indirectly indicate the product is produced by Malay producer.

The use of language on consumer purchasing behavior has received recognition and attention of academics especially in understanding consumer preference and acceptance of global brand. Language expresses, embodies and symbolized culture reality (Kramsch, 1998). Previous research has shown that language differences may affect consumer information processing (Schmitt, Pan, \& Tavassoli, 1994). However, not many studies on 
It's not just a brand name: The impact of language on consumer attitude and behavior

branding in Malaysia especially related with the language use in local brand names are conducted by local researcher.

Language is part of the culture and it is one primary aspect in a culture that differentiates groups of people (Brown, 1963). Language is therefore the key to develop an understanding and communicating with the various world cultures (Swift, 1991). Consumers normally employ their local language and culture as a way to create identity of a brand (Usunier \& Shaner, 2002). Thus it is necessary for companies that conduct business in multilingual societies to decide what language to use for their brand name, product labels or advertising (de Run \& Chin, 2006).

In 2007, there were 6,287,900 Chinese in Malaysia (Department of Statistics Malaysia, 2007). Chinese in Malaysia are mainly the descendents of immigrants from China (Lee \& Tan, 2000). Mandarin is the written and spoken language taught at school but there are numerous spoken dialect groups (Lee \& Tan, 2000). The variation of Chinese dialects, implementation of the Malaysian National Language Policy and education system has brought about the rise of the Chinese as the largest multilingual society in Malaysia (Omar, 1982). Most of the Chinese are bilinguals or multilingual, they can speak Mandarin, Bahasa Malaysia, English as well as their own Chinese dialect. Mandarin and Chinese dialects is the language used when they communicate with people within their ethnic group. When Chinese communicate with different ethnic groups, a widely spoken second language such as Bahasa Malaysia or English is used (Omar, 1982).

It is broadly recognized that brand names play a vital role in marketing products and services in their acceptance by public (Charmasson, 1988). Previously, studies conducted were focused on the guidelines and criteria to develop effective brand names (Collins, 1977; McNeal \& Zeren, 1981; McCarthy \& Perreault; 1987). Majority of the studies were conducted in Western countries and on products which are branded in Western European languages, only a few studies were focused at the brand naming in Asian Culture (Chan \& Huang, 2001).

Malaysia as a multilingual society poses particular problems for companies. Brand names with various languages were easily found in Malaysia market. Language also plays a vital role in persuading consumer to purchase a product or service (Dyer, 1982), especially if the product's target market is a specific group, such as an ethnic community (de Run \& Chin, 2006). Groups of people from different cultural backgrounds who speak different languages are different in the way they see things around them (Whorf, 1950). Hence it is necessary to examine the impact of different languages used in brand names in Malaysia. This research attempts to address the impact of languages use in brand names by examining Malaysian Chinese consumer's attitude towards the Bahasa Malaysia, English and Chinese language brand names. Furthermore, their purchase intention towards the brand will also be investigated.

The Speech Accommodation Theory (SAT) is used as the theoretical basis of the study. The SAT explains how speakers can communicate in different language, alter or accommodate their linguistic style to their audience, and obtain a positive or negative reaction (Giles et al., 1973).The Speech Accommodation Theory (SAT) is adapted to the impact of language use in brand names to Chinese consumers. Chinese consumers react towards the language use in brand name based on their language style. Since the Chinese language brand name accommodates their language style, they will have favorable attitude towards the brand and its products. Conversely, Chinese consumer will have negative attitude toward the brand and its products as the Bahasa Malaysia brand names did not accommodates their language style. The Speech Accommodation Theory (SAT) is the relevant theory acts as supporting tool for this study to investigate the impact of language use in brand names on Malaysian Chinese consumer. Refer to Figure 1.

Based on the discussion on Chinese consumers' reaction towards the brand names of different languages, the following hypotheses were constructed:

$\mathbf{H}_{1}$ : Chinese consumers will have significant positive reaction towards the use of Chinese language brand 
name.

$\mathbf{H}_{2}$ : Chinese consumers will have negative reaction towards the use of Malay language brand name.

$\mathbf{H}_{3}$ : Chinese consumers will have negative reaction towards the use of English language brand names.

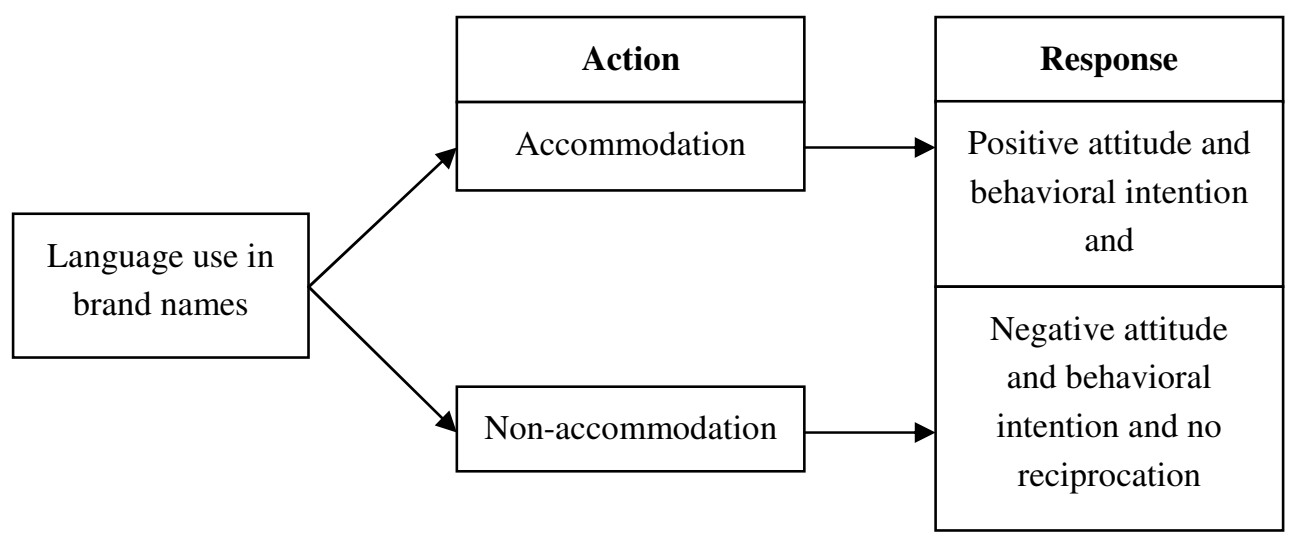

Figure 1. Adaption of Speech Accommodation Theory

Source: Giles et al, 1973

\section{Methodology}

Since a 3 (Language in used in brand names: English, Chinese and Malay) $\times 1$ (Ethnicity) factorial design was employed, minimum sample size was calculated based on a minimum of 50 respondents per cell. Other research utilized a lesser number per cell (15 per cell) (Goldberg and Gorn, 1974) to a high number of 80 respondents per cell (Clarke, 1984). Convenience sampling was used where questionnaires were distributed to students of a local University to take home with them during their holidays. Questionnaires were then distributed to their family, friends and neighbors from six states that had high Chinese population namely Selangor, Johor, Perak, Wilayah Persekutuan Kuala Lumpur, Pulau Pinang, and Sarawak (Department of Statistics Malaysia, 2007).

Brand names of local food products were selected because many of local food producers named their product based on their culture of origin (Harun, Sondoh, A Wahid, \& Mohammad, 2006). Exploratory test were carried out to obtain the three names to be used. The three brand names used in this study are Kopimas (Bahasa Malaysia), Aik Cheong (Chinese) and Power Root (English). These three languages were selected because Bahasa Malaysia and English is compulsory subject in primary and secondary school and Chinese language is the respondent's ethnic tongue.

The questionnaire was designed with three parts. The first part is the demographic factors. The second part is the perception of the brand name. It includes the questions taken from previous studies, measuring respondent's attitude towards brand name (Mitchell \& Olson, 1981), attitude towards company (Peterson, Wilson \& Brown, 1992), purchase intention (Masheswaran \& Sternthal, 1990) and word of mouth (Becker \& Kaldenberg, 2000). Lastly, the third part is the open ended questions related to the willingness to pay for the brand. A six-point Likert Scale questionnaire was used and the interval scale are strongly disagree (1), disagree (2), slightly disagree (3), slightly agree (4), agree (5) and strongly agree (Chang, 1994). A total number of 255 sets questionnaires were distributed.

\section{Findings}

255 completed questionnaires were collected ( 85 questionnaires for Power Root, 85 questionnaires for Aik Cheong and 85 questionnaires for Kopimas). However, 15 sets were eliminated because they were incomplete. The response rate was $94.12 \%$ and is considered good (Bradley, 2007). As for willingness to pay, 119 (49.6\%) 
It's not just a brand name: The impact of language on consumer attitude and behavior respondents stated they were willing to pay if the price of the product was increased and $121(50.4 \%)$ said otherwise. The profile of the respondents is depicted in Table 1.

\section{Table 1}

Respondents' Profile

\begin{tabular}{|c|c|c|c|}
\hline \multicolumn{2}{|c|}{ Variables } & \multirow{2}{*}{$\frac{\text { Frequency }}{106}$} & \multirow{2}{*}{$\frac{\text { Percent }}{44.2}$} \\
\hline Gender & Male & & \\
\hline & Female & 134 & 55.8 \\
\hline \multirow[t]{4}{*}{ Age } & $20-29$ & 141 & 58.8 \\
\hline & $30-39$ & 53 & 22.1 \\
\hline & $40-49$ & 31 & 12.9 \\
\hline & $50-59$ & 15 & 6.3 \\
\hline \multirow[t]{6}{*}{ State } & Selangor & 65 & 27.1 \\
\hline & Johor & 50 & 20.8 \\
\hline & Perak & 34 & 14.2 \\
\hline & Kuala Lumpur & 31 & 12.9 \\
\hline & Penang & 31 & 12.9 \\
\hline & Sarawak & 29 & 12.1 \\
\hline \multirow[t]{2}{*}{ Education Type } & Chinese Educated & 181 & 75.4 \\
\hline & English Educated & 59 & 24.6 \\
\hline \multirow[t]{4}{*}{ Religion } & Buddhist & 175 & 72.9 \\
\hline & Christian & 59 & 24.6 \\
\hline & Catholic & 1 & 0.4 \\
\hline & NA & 5 & 2.1 \\
\hline
\end{tabular}

Mean score and Anova findings for all dependent variables by brand name are showed in Table 2.

Table 2

Mean and Anova for Variables by Brand Name

\begin{tabular}{lllllll}
\hline \multicolumn{1}{c}{ Variables } & \multicolumn{2}{c}{ Aik Cheong } & \multicolumn{2}{c}{ Kopimas } & \multicolumn{2}{c}{ Power Root } \\
\cline { 2 - 7 } & Mean & $S D$ & Mean & $S D$ & Mean & $S D$ \\
\hline $\begin{array}{l}\text { Attitude towards the brand } \\
(\mathrm{F}=27.59, \text { Sig=.000) }\end{array}$ & 4.04 & 0.91 & 3.25 & 0.83 & 4.28 & 0.99 \\
\hline $\begin{array}{l}\text { Attitude toward the company } \\
(\mathrm{F}=10.79, \text { Sig=.000) }\end{array}$ & 3.60 & 0.87 & 3.07 & 1.40 & 3.83 & 0.76 \\
\hline $\begin{array}{l}\text { Purchase Intention } \\
\text { (F=19.16, Sig=.000) }\end{array}$ & 3.90 & 0.96 & 3.08 & 0.96 & 4.09 & 1.33 \\
\hline $\begin{array}{l}\text { Word of Mouth } \\
\text { (F=19.72, Sig=.000) }\end{array}$ & 3.96 & 1.01 & 3.16 & 0.93 & 4.08 & 1.08 \\
\hline
\end{tabular}

The ANOVA findings indicated a clear difference between brands and further analysis was then carried out using t-test. Mean score and t-test findings are indicated in Table 3. The findings indicate that there was a positive preference for Chinese brand name over Malay brand name and also a positive preference for English brand name over Malay brand name. There was also no difference is response for Chinese brand name over English brand name.

The frequency of those who said will or will not be willing to pay more if the price of the product is increased together with Mann-Whitney test findings is depicted in Table 4. The findings mirror the findings based on attitudinal and behavioral responses. Respondents were more willing to pay if price increased for 
de Run, E. C., Yee, T. C., \& Khalique, M.

Chinese brand name over Malay brand name as well as English brand name over Malay brand name. There was no difference between Chinese and English brand name. This and the above findings provide support for $\mathrm{H} 1$ and

H2. However, H3 is not supported.

Table 3

Mean and t-test for Variables by Brand Name

\begin{tabular}{|c|c|c|c|c|c|c|}
\hline \multirow{2}{*}{ Variables } & \multicolumn{2}{|c|}{ Aik Cheong } & \multicolumn{2}{|c|}{ Kopimas } & \multicolumn{2}{|c|}{ Power Root } \\
\hline & Mean & $S D$ & Mean & $S D$ & Mean & SD \\
\hline Attitude towards the brand & $4.04 * *$ & 0.91 & 3.25 & 0.83 & & \\
\hline Attitude toward the company & $3.60 *$ & 0.87 & 3.07 & 1.40 & & \\
\hline Purchase Intention & $3.90 * *$ & 0.96 & 3.08 & 0.96 & & \\
\hline Word of Mouth & $3.96 * *$ & 1.01 & 3.16 & 0.93 & & \\
\hline Attitude towards the brand & & & 3.25 & 0.83 & $4.28 * *$ & 0.99 \\
\hline Attitude toward the company & & & 3.07 & 1.40 & $3.83 * *$ & 0.76 \\
\hline Purchase Intention & & & 3.08 & 0.96 & $4.09 * *$ & 1.33 \\
\hline Word of Mouth & & & 3.16 & 0.93 & $4.08 * *$ & 1.08 \\
\hline Attitude towards the brand & 4.04 & 0.91 & & & 4.28 & 0.99 \\
\hline Attitude toward the company & 3.60 & 0.87 & & & 3.83 & 0.76 \\
\hline Purchase Intention & 3.90 & 0.96 & & & 4.09 & 1.33 \\
\hline Word of Mouth & 3.96 & 1.01 & & & 4.08 & 1.08 \\
\hline
\end{tabular}

Note. Significant Difference at $* p<0.05, * * p<0.001$

\section{Table4}

Frequency and Mann-Whitney for Variables by Brand Name

\begin{tabular}{|c|c|c|c|c|c|c|c|}
\hline \multirow{2}{*}{\multicolumn{2}{|c|}{ Variables }} & \multicolumn{2}{|c|}{ Aik Cheong } & \multicolumn{2}{|c|}{ Kopimas } & \multicolumn{2}{|c|}{ Power Root } \\
\hline & & Freq & $\%$ & Freq & $\%$ & Freq & $\%$ \\
\hline \multirow{6}{*}{$\begin{array}{l}\text { If the price of the brand is } \\
\text { increased, are you willing to pay? }\end{array}$} & Yes & $49 * *$ & 61.3 & 22 & 27.5 & & \\
\hline & No & 31 & 38.8 & $58 * *$ & 72.5 & & \\
\hline & Yes & & & 22 & 27.5 & $48 * *$ & 60.0 \\
\hline & No & & & $58 * *$ & 72.5 & 32 & 40.0 \\
\hline & Yes & 49 & 61.3 & & & 48 & 60.0 \\
\hline & No & 31 & 38.8 & & & 32 & 40.0 \\
\hline
\end{tabular}

Note. Significant Difference at $* p<0.05, * * p<0.001$

\section{Discussion}

The findings clearly show that the Chinese respondents prefer the Chinese language brand name over Malay language brand name. It also shows that the Chinese respondents prefer the English language brand name over Malay language brand name and that there is no difference in their responses to English and Chinese brand names. This seems to contradict the SAT where the Chinese respondents prefer the English brand name as equally as their own language based brand name. The respondents preferred their own language brand name over the Malay brand name, which supports the SAT but then there is a preference for another language too. This provides the contradiction to the SAT and brings up several issues.

The first is the impact of English in Malaysia. Malaysia past history of colonialism has introduced English as a language of the colonizers (Mandal, 2000). English is also the lingua franca of the world

The second is the status of Chinese language in Malaysia. The Chinese in Malaysia are nearly all well 
It's not just a brand name: The impact of language on consumer attitude and behavior

schooled in English, Malay and Chinese (Mandarin and/or their own dialect). Most Chinese at the very least are bilingual. Mandarin is the medium of instruction in the Chinese vernacular schools. Nevertheless there are sections of Chinese in Malaysia who are educated in the Malay and/or English based schools and who speak and prefer English. However in this study, no Mandarin writing was used, just the brand name Aik Cheong, which for a Malaysian can be easily termed as Chinese. So the findings suggest a larger than language issue and more of a perception of the culture of Chinese as a whole that comes with a Chinese language brand name.

The third is the way the cues are processed. Past studies show that adolescents from different ethnic group process cues in advertising differently (Butt and De Run, 2010; Butt and De Run, 2011). Studies have shown that Indians also seem to prefer both English and their own mother tongue (de Run, Elanjothi, \& Jee, 2010). This suggests that the non-dominant ethnic groups in Malaysia have a preference for English more than the Malay language and warrants further investigation.

Nevertheless there is a clear and certain preference for English brand name. Malaysian Chinese see English as an important language for both occupational and spatial mobility (Tan, 2005). The English language is a common entity among the inhabitants of the world (Block, 2008). This sense of English as an important language to escape the bamboo curtain and for business and migration purposes may have allowed it to overshadow their own language brand name.

Aside from that, most products in Malaysia that are with an English brand name are indicative of their origins. Consumers commonly have country stereotyping, a more positive perception of merchandises from developed countries than their lesser developed counterparts (Wang \& Lamb, 1983). Such preference may also be due to past history of colonialism in Malaysia (Mandal, 2000) that induces perception of the superiority of Westerners/Western language hence Western brand names are observed to carry a higher prestige (Marcoux, Filialtrault, \& Che'ron, 1997). Malaysians perceived them to be of high quality foreign products (Liefeld, 2004; Balabanis and Diamantopoulos, 2008). If a brand name is perceived as foreign, it then brings all the appropriate connotations (quality, glamour, and price) that set it apart from a local brand (Alden, Steenkamp, \& Batra, 1999; Batra et al., 2000). This is known in Malaysia as the 'Mat Salleh' or Westerner syndrome (Change Perception by Buying Malaysian, n.d.). Perhaps that is why many companies in Malaysia have English or English sounding brand names.

A brand name in Chinese or Malay will therefore not carry such connotations. It would immediately be seen as a local brand. When coming across such a choice, it is clear that the Chinese have positive attitudes and behavior towards their own language based brand name. This supports the SAT. It also is indicative of the social aspect in Malaysia where language segregates the society (Omar, 1982). Chinese prefer Chinese language schools, speak Chinese amongst themselves and only speak Bahasa when they are forced to do so. Thus the choice of a Chinese brand name is not a shock.

It is reasonable to assert that Malaysian Chinese prefer their own language and English brand names over Malay language brand name and are willing to pay accordingly. The findings suggest that language choice of a brand name is an important consideration for companies. Based on such an outcome, a foreign investor/company should always emphasize their foreignness in their marketing efforts in Malaysia through an English language brand name. Nevertheless there is a caveat, as to who are the companies target markets, as further study is required to note whether Malays will also respond accordingly. The findings also suggest that companies may adopt premium pricing strategies with appropriate language based brand names. One must also take note that the target market must be identified and that willingness to pay does not translate to actual purchase.

\section{Conclusion}

Chinese Malaysians are at the minimum multilingual. Nevertheless when it comes to attitude and behavior towards brand names, it seems that the Chinese prefer English. When the choice is limited to Malay and Chinese, it is still Chinese. This provides a contradiction to the SAT and a lot to think about for management. A clear 
de Run, E. C., Yee, T. C., \& Khalique, M.

limitation is that the brands used are real life brand that carry their own brand equity and meaning. This may have had some impact of the response by our respondents. Aside from that the study only looked at Chinese response and not other groups such as the Peranakan Chinese or even other ethnic groups. Future research can take measures to mitigate these limitations by carrying out fictitious brand names and also for different product categories. Other languages can also be taken into consideration, such as Tamil. Since Malaysia is a multi ethnic country, comparative studies could also be carried out.

\section{References:}

Ahmad, F. S., \& Baharun, R. (n.d.). A crucial role of rntrepreneur in B2B branding: A case from Malaysia. Faculty of Management and Human Resource Development, Universiti Teknologi Malaysia.

Alden, D. L., Steenkamp, J. B. E. M., \& Batra, R. (1999). Brand positioning through Advertising in Asia, North America, and Europe: the role of global consumer culture. Journal of Marketing, 63, 75-87. <http://dx.doi.org/10.2307/1252002>

Balabanis, G., \& Diamantopoulos, A. (2008). Band origin identification by consumers: a classification perspective. Journal of International Marketing, 16(1), 39-71. <http://dx.doi.org/10.1509/jimk.16.1.39>

Batra, R., Ramaswamy, V., Alden, D. L., Steenkamp, J. B. E. M., \& Ramachander, S. (2000). Effects of brand local/nonlocal origin on consumer attitudes in developing countries. Journal of Consumer Psychology, 9(2), 83-95. <http://dx.doi.org/10.1207/S15327663JCP0902_3 >

Becker, B. W., \& Kaldenberg, D. O. (2000). Factors Influencing the Recommendation of Nursing Homes. Marketing Health Services, 20(4), 22-28.

Block, D. (2008). Language Education and Globalization. In N. H. Hornberger (Ed.), Encyclopedia of language and education (pp. 31-43). United States: Springer. <http://dx.doi.org/10.1007/978-0-387-30424-3_33>

Boddewyn, J. J., Soehl, R., \& Picard, J. (1986). Standardization in international market, is Ted Levitt in fact right? Business Horizons, 29, 69-75. <http://dx.doi.org/10.1016/0007-6813(86)90040-6>

Bradley, N. (2007). Marketing research: Tools and techniques. United States: Oxford University Press Inc.

Brown, I. C. (1963). Understanding other culture. Englewood Cliffs, N.J: Prentice Hall.

Butt, M. M., \& De Run, E. C. (2010). Ethnic advertising: Adolescents' attitudes towards target and non-target advertisements. Young Consumers, 11(3), 189 - 203

Butt, M. M., \& De Run, E. C. (2011). Do target and non-target ethnic group adolescents process advertisements differently? Australasian Marketing Journal. <http://dx.doi.org/10.1108/17473611011074269>

Chan, A. K. K., \& Huang, Y. Y. (1997). Brand naming in China: A linguistic approach. Marketing Intelligence \& Planning, 15(5), 227-234. <http://dx.doi.org/10.1108/02634509710177297>

Chan, A. K. K., \& Huang, Y. Y. (2001). Principle for brand name in Chinese: the case of drinks. Marketing Intelligence \& Planning, 19(5), 309-318. < http://dx.doi.org/10.1108/EUM0000000005648>

Chang, L. (1994). A Psychometric Evaluation of 4- point and 6- point Likert scales in relation to reliability and validity. Applied Psychology Measurement, 18(3), 205-215.

$<$ http://dx.doi.org/10.1177/014662169401800302>

Change perception by buying Malaysian. (n.d.). Retrieved January 6, 2011 from http://web10.bernama.com/kpdnhep/v2/index.php?lang=en\&sid=newsdetailkbbm\&id=417492

Charmasson, H. (1988). The name is the game: How to name a company or product. Homewood, IL: Dow Jones-Irwin.

Clarke, T. K. (1984). Situational factor affecting preschoolers' responses to advertising. Academy of Marketing Science, 12(4), 25-40. <http://dx.doi.org/10.1007/BF02721797>

Collins, L. (1977). A name to conjure with. European Journal of Marketing, 11(5), 340-363.

de Run, E. C., \& Chin, S. F. (2006). Language use in packaging: The reaction of Malay and Chinese consumers in Malaysia. Sunway Academic Journal, 3, 133-145.

de Run, E. C., Elanjothi, M, \& Jee, T. W. (2010). Testing real world advertisement language cues impact on 
It's not just a brand name: The impact of language on consumer attitude and behavior

dominant and non dominant ethnic groups: Comparing Malay and Indians in Malaysia. International Journal of Business and Society, 11(2).

Department of Statistics Malaysia. (2007). Year book of statistics: Malaysia 2007. Putra Jaya: Department of Statistics Malaysia.

Doole, I., \& Lowe, R. (1999). International marketing strategy. Singapore: International Thomson Business Press.

Dyer, G. (1982). Advertising as communication (Studies in communication). London: Routledge.

Giles, H., Taylor, D. M., \& Bourhis, R. Y. (1973). Toward a theory of interpersonal accommodation through speech accommodation: Some Canadian data. Language in Society, 2, 177-192. $<$ http://dx.doi.org/10.1017/S0047404500000701>

Goldberg, M. E., \& Gorn, G. J. (1974). Children's reactions to television advertising: an experimental approach. Journal of Consumer Research, 1(2), 69. <http://dx.doi.org/10.1086/208593>

Harun, A., Sondoh, S., A. Wahid, N., \& Mohammad, O. (2006). Perception, attitude and behaviour towards multilingual brand names and brand name linguistics in Malaysia. Across cultural study. Paper presented at the Conference Proceeding SME and Marketing, Penang, 2007.

Hashim, A. (2003). Language policies and language education issues in Malaysia. In J. Lindsay \& Y. Y. Tan (Ed.), Babel or behemoth: Language trends in Asia (Vol. 1 of Asia Trends, pp. 93). Singapore: Asia Research Institute, National University of Singapore.

Keller, K. L. (1993). Conceptualizing, measuring and managing customer-based brand equity. Journal of Marketing, 57, 1-22. <http://dx.doi.org/10.2307/1252054>

Kotler, P., \& Armstrong, G. (1997). Marketing: An introduction (4th ed.). Englewood Cliffs, NJ: Prentice- Hall. Kramsch, C. (1998). Language and culture. Oxford: Oxford University Press.

Lee, K. H., \& Tan, C. B. (2000). The Chinese in Malaysia. Selangor: Oxford University Press.

Liefeld, J. P. (2004). Consumer knowledge and use of country-of-origin information at the point of purchase. Journal of Consumer Behaviour, 4(2), 85-97. <http://dx.doi.org/10.1002/cb.161>

Maheswaran, D., \& Sternthal, B. (1990). The effects of knowledge, motivation, and type of message on ad processing and product judgements. Journal of Consumer Research, 17, 66-73. $<$ http://dx.doi.org/10.1086/208537>

Mandal, S. K. (2000). Reconsidering cultural globalization: The English language in Malaysia. Third World Quarterly, 21(6), 1001-1012. <http://dx.doi.org/10.1080/01436590020012007>

Marcoux, J-S., Filialtrault, P., \& Che'ron, E. (1997). The attitudes underlying preferences of young urban educated Polish consumers towards products made in Western countries. Journal of International Consumer Marketing, 9(4), 5-29. <http://dx.doi.org/10.1300/J046v09n04_02>

McCarthy, E. J., \& Perreault, W. D. Jr. (1987). Basic marketing: A managerial approach. Homewood, IL: Irwin.

McNeal, J. U., \& Zeren, L.M. (1981). Brand name selection for consumer products. MSU Business Topics, 35-39.

Mitchell, A. A., \& Olson, J. C. (1981). Are product attribute belief the only mediator of advertising effects on brand attitude. Journal of Marketing Research, 18, 318-322. <http://dx.doi.org/10.2307/3150973>

Omar, A. H. (1982). Language and society in Malaysia. Kuala Lumpur: Dewan Bahasa Dan Pustaka.

Peterson, R. A., Wilson, W. R., \& Brown, S. P. (1992). Effects of advertised customer satisfaction claims on consumer attitudes and purchase intention. Journal of Advertising Research, 32(2), 34-40.

Schmitt, B. H., Pan, Y., \& Tavassoli, N. T. (1994). Language and consumer memory: The impact of linguistic differences between Chinese and English. Journal of Consumer Research, 21, 419-431. $<$ http://dx.doi.org/10.1086/209408>

Swift, J. S. (1991). Foreign language ability and international marketing. European Journal of Marketing, 25(12), 36-49. <http://dx.doi.org/10.1108/EUM0000000000634>

Tan, C. B. (2005). Chinese in Malaysia. In M. Ember, C. R. Ember, \& I. Skoggard (Ed.), Encyclopaedia of diasporas-immigrant and refugee culture around the world (pp. 697-705). United States: Springer.

Usunier, J. C., \& Shaner, J. (2002). Using linguistic for creating better international brand name. Journal of Marketing Communication, 8(4), 211-218. <http://dx.doi.org/10.1080/13527260210146000> 
de Run, E. C., Yee, T. C., \& Khalique, M.

Wang, C., and Lamb, C. (1983). The impact of selected environmental forces upon consumers' willingness to buy foreign products. Journal of the Academy of Marketing Science, 11(2), 71-84. <http://dx.doi.org/10.1007/BF02721862>

Whorf, B. L. (1950). Four articles on metalinguistics. Washington, DC: Foreign Service Institute 